Nartsiss SHUKURALIEVA

DOI : $10.14746 /$ pp.2017.22.1.13

Bydgoszcz

Artur LIPIŃSKI

Poznań

\title{
Uwarunkowania legitymizacji władzy w systemach autorytarnych. Casus państw Azji Centralnej
}

\begin{abstract}
Streszczenie: Legitymizacja wraz z kooptacją oraz represją stanowi trzy zasadnicze filary stabilności reżimu autokratycznego, a wyjaśnianie mechanizmów trwałości powinno uwzględniać skomplikowane relacje pomiędzy wymienionymi zmiennymi. Elity reżimów autorytarnych systematycznie formułują legitymizacyjne roszczenia mające usprawiedliwiać ich władzę, a proces ich skutecznej dystrybucji oraz instytucjonalizacji zależy od szeregu warunków i mechanizmów. Zadaniem niniejszego tekstu jest analiza wybranych warunków efektywności i mechanizmów legitymizacji w państwach autorytarnych, w oparciu o przykłady pochodzące z krajów Azji Centralnej.
\end{abstract}

Słowa kluczowe: legitymizacja, represje, kooptacja, Azja Centralna, autorytaryzm

\section{Wprowadzenie}

ategoria legitymizacji jest jednym z najpopularniejszych i zarazem najważniejszych konceptualnych narzędzi pozwalających na badanie zjawiska władzy i stabilności reżimu politycznego. Popularność kategorii nie przekłada się jednak na jednoznaczne jej rozumienie przez badaczy. Nie jest jasne na przykład, czy odnosi się ona do rządzących, czy rządzonych, czy dotyczy właściwości systemu politycznego, praktyk, czy przekonań, wreszcie, czy powinna być zarezerwowana wyłącznie do krajów demokratycznych, czy też krajów autorytarnych. W literaturze spotkać się można z trzema rodzajami zarzutów krytykujących stosowanie pojęcia legitymizacji do analizy reżimów autorytarnych. Po pierwsze, krytyki normatywne twierdzące, że systemy autorytarne opierają się na stosowaniu siły, stąd nie mogą być postrzegane jako dysponujące legitymacją. W takim ujęciu prawomocna autokracja byłaby oksymoronem nieznajdującym desygnatu w rzeczywistości. Po drugie, krytyki na poziomie substancjalnym podkreślają, iż legitymizacja nie ma większego znaczenia dla stabilności systemu. Reżimy autorytarne nie muszą odwoływać się do poparcia społecznego, swoją równowagę budują przy pomocy innych mechanizmów. Trzeci nurt krytyki zwraca uwagę na nierozwiązane problemy metodologiczne związane z mierzeniem legitymizacji w reżimach autorytarnych (Gerschewski, 2013, s. 18).

Jeśli przyjąć weberowskie ujęcie legitymizacji, traktujące ją jako społecznie podzielaną wiarę w prawomocność, to zauważyć wypada, iż w warunkach autorytarnych niezwykle trudno jest zmierzyć rzeczywiste przekonania społeczne (Weber, 2002, s. 158). Badania opinii publicznej z oczywistych względów nie przynoszą wiarygodnych rezultatów, a oficjalne deklaracje różnią się od prywatnie wyznawanych poglądów (Magaloni, 
2006, s. 1). Ocena stopnia społecznego poparcia dla reżimu, jeśli nie zachodzą wydarzenia protestacyjne czy rewolucje (jak np. rewolucja tulipanowa z 2005 r., czy rewolucja kwietniowa z 2010 r. w Kirgistanie), jest więc bardzo utrudniona. Ponadto w przypadku krajów rozległych terytorialnie i o dużej liczbie ludności trudne jest zbadanie nawet reprezentatywnej próby (Sandby-Thomas, 2011, s. 27). Choć, jak zauważył w Trzeciej fali demokratyzacji S. P. Huntington: „stosując pojęcie legitymizacji wchodzimy na grząski grunt" to ,jest ono jednak niezbędne dla zrozumienia problemów, przed którymi stają reżimy autorytarne końca XX wieku" (Huntington, 1995, s. 55). Zdaniem J. Gerschewskiego (2013, s. 29) legitymizacja wraz z kooptacją oraz represją stanowi trzy zasadnicze filary stabilności reżimu autokratycznego, a wyjaśnianie mechanizmów trwałości powinno uwzględniać skomplikowane relacje pomiędzy wymienionymi zmiennymi. Jak podkreśla, legitymizacja znacznie zmniejsza koszty perswazji podejmowanej przez elity wobec aparatu oraz społeczeństwa, a także zmniejsza prawdopodobieństwo pojawienia się personalnych alternatyw względem rządzących.

Pojęcie legitymizacji jest szczególnie przydatne dla wyjaśnienia źródeł politycznej stabilności reżimów Azji Centralnej, zarówno tych, które nigdy nie weszły na ścieżkę demokratyzacji, jak i tych, które pozostają w przestrzeni hybrydalnej, gdzie formalne instytucje demokratyczne (np. rywalizacyjne wybory) (Diamond, 2002; Levitsky, Way, 2010), są w mniejszym, bądź większym stopniu modyfikowane przez nieformalne praktyki służące zabezpieczaniu władzy rządzących (np. poprzez ograniczanie praw wyborczych, wolności mediów, czy prześladowanie opozycji ${ }^{1}$. Mechanizmy represji, czy też kooptacji nie wystarczają dla wyjaśnienia fenomenu trwałości centralnoazjatyckich autorytaryzmów, a ponadto nie uwzględniają szeregu legitymizacyjnych działań niedemokratycznych elit, których celem jest uzasadnianie istniejącego porządku. Koncentracja na mechanizmach represyjnych utrudnia również zrozumienie, dlaczego autorytarni władcy decydują się ponosić koszty związane z instytucjonalizacją perswazji. Zadaniem niniejszego tekstu jest analiza wybranych warunków efektywności i mechanizmów legitymizacji w państwach autorytarnych, w oparciu o przykłady pochodzące z krajów Azji Centralnej. Nadmienić należy, że koncentracja uwagi na roszczeniach legitymizacyjnych formułowanych przez elity polityczne państw niedemokratycznych nie oznacza przyjęcia założenia, że ich działania są zawsze skuteczne. Chodzi raczej o słabszą tezę, że mają one znaczenie dla reprodukcji stabilności niedemokratycznych reżimów, nie będąc jedynie pozbawioną konsekwencji propagandową mową.

\section{Kontrola podmiotów formulujących roszczenia podważające oficjalną formulę legitymizacyjną}

Po pierwsze, reżimy autorytarne mogą okazać się skuteczniejsze od demokratycznych w promowaniu partykularnych sposobów reprezentacji świata społeczno-politycz-

${ }^{1}$ Według Andreasa Schedlera ,autorytaryzmy wyborcze organizują wybory wielopartyjne, ale naruszają liberalno-demokratyczne zasady systematycznie i w stopniu tak głębokim, że wybory stają się nie tyle instrumentem demokracji, ile rządów autorytarnych" (Zob. Schedler, 2006, s. 3; zob. także: Morse, 2012, s. 161-198). Przeglądu obszernej literatury przedmiotu dokonał D. Brancati (2014, s. 313-326). 
nego ze względu na eliminację, bądź ograniczanie pluralizmu, większe zasoby i strukturalne możliwości niezbędne do monopolizacji dyskursu politycznego (Schlumberger, 2010, s. 236). Z tego powodu wszystkie reżimy autorytarne przeznaczają potężne zasoby na kontrolę systemów medialnych, a także kontrolę potencjalnych podmiotów formułujących roszczenia podważające oficjalną formułę legitymizacyjną2. W zależności od charakteru systemu politycznego kontrola może być całkowita i często odwołująca się do represji (skonsolidowane autorytaryzmy), bądź też opierać się na doraźnych, okresowych interwencjach, które nie podważałyby w sposób zasadniczy formalnej zasady wolności mediów (,miękkie" autorytaryzmy) ${ }^{3}$.

Model skonsolidowanego autorytaryzmu reprezentowały Uzbekistan i Turkmenistan uznawane przez Freedom House za najbardziej represyjne państwa świata ${ }^{4}$. Państwa te charakteryzuje brak partii opozycyjnych, wolnych mediów, surowe kary za wszelkie przejawy niesubordynacji wobec władzy. Przed zniesieniem kary śmierci w tych krajach (w Turkmenistanie w 1999 r., w Uzbekistanie 2008 r.) mogła być ona orzekana za wiele przestępstw, w tym za przestępstwa przeciwko państwu i panującej władzy. Turkmeński kodeks karny (УК Туркменистана) z dnia 1 stycznia 1998 r. dopuszczał możliwość orzekania kary śmierci za trzynaście czynów, w tym za siedem określanych jako przestępstwa polityczne. Należały do nich: napad na osoby objęte ochroną międzynarodową (art. 170 ust. 2), zdrada państwa (art. 171), szpiegostwo (art. 172), dywersja (art. 173 ust. 2), spisek w celu przejęcia władzy (art. 174 ust. 2), zamach na prezydenta Turkmenistanu (art. 176 ust. 1), terroryzm (art. 271 ust. 3). Republika natomiast nie tylko zajmowała pierwsze miejsce na świecie ze względu na liczbę wyroków skazujących w proporcji na jednego mieszkańca ${ }^{5}$, ale także ze względu na wykonane wyroki. Prawie wszystkie osoby skazane na karę śmierci w latach 1992-1997 zostały rozstrzelane (Мамедова, 2007, s. 8; szerzej: Shukuralieva, Sobczak, 2014, s. 88-102). Formy nadzoru społecznego były wzmacniane również za czasów prezydenta Gurbanguly Berdymuchammedowa. Za pomocą najnowocześniejszego systemu inwigilacyjnego, służby bezpieczeństwa monitorowały naziemne i satelitarne linie telefoniczne, faksy, pocztę elektroniczną i internet (Halonen, Frazier, 2010, s. 322).

Z drugiej strony, typowym przykładem „miękkiego” autorytaryzmu był Kirgistan, gdzie w ciagu dwudziestu lat doszło do dwukrotnego obalenia skorumpowanej władzy. Wydarzenia te określane mianem rewolucji marcowej (usunięcie prezydenta Askar Aka-

${ }^{2}$ Dobrym przykładem są strategie władz krajów Azji Centralnej na tzw. kolorowe rewolucje na obszarze postsowieckim (zob. np. Polese, Ó Beacháin, 2011; Finkel, Brudny, 2012).

${ }^{3}$ Do takich środków należy np. wymuszona bodźcami zewnętrznymi autocenzura, karne i cywilne procesy o zniesławienie, nieprzyznawanie, bądź odbieranie licencji, czy utrudnienia w dostępie do informacji. Na temat Kirgistanu szerzej E. Freedman (2009, s. 850-853). Na temat innych krajów obszaru postradzieckiego zob. A. Richter (2008, s. 307-324). O podobnych mechanizmach, obejmujących również media społecznościowe w odniesieniu do Kazachstanu pisze L. Anceschi (2015).

${ }^{4}$ Raporty The World's Most Repressive Societies (2002-2012) oraz Worst of the Worst: The World's Most Repressive Societies (2002-2012).

${ }^{5}$ Według nieoficjalnych danych, na które powołuje się Amnesty International, tylko w 1994 r. Turkmenistan 16 razy wyprzedził Chiny pod względem liczby wykonanych wyroków śmierci w relacji do ogólnej liczby obywateli (zob. szerzej Правозащитный центр „Мемориал”, 1999, s. 33; Amnesty International, 1997, s. 3). 
jewa w 2005 r.) i kwietniowej (usunięcie prezydenta Kurmanbek Bakijewa w 2010 r.) odzwierciedlały specyfikę republiki charakteryzującej się największym w regionie zagęszczeniem organizacji pozarządowych, wolnych mediów oraz silną mobilizacją społeczną. Wedle danych Ministerstwa Spraw Wewnętrznych w ciągu tylko dziewięciu miesięcy 2011 r. w kraju zorganizowano 1013 mityngów i akcji protestu (501 odbyło się pod hasłami postulatów socjalnych, natomiast 512 miało charakter polityczny) (В Кыргызстане, 2011). Jednak realizacja systematycznie deklarowanych przez władzę postulatów wprowadzenia reform demokratyzacyjnych nie wychodziła zazwyczaj poza sferę proceduralnego legalizmu i organizacji wyborów. Na poziomie politycznym obowiązywały formalne mechanizmy demokracji proceduralnej, które pozwalały na istnienie, ale już nie wygrywanie wyborów przez ugrupowania konkurencyjne. Oznaczało to systematyczne przeprowadzanie wyborów, wyniki których były z góry przesądzone. Zapewniano również wolność słowa oraz wypowiedzi, w tym wolność mediów, zachowując jednak istotne ograniczenia. Na poziomie społecznym, pozwalano na prowadzenie działalności stowarzyszeń obywatelskich, ale przy pomocy wielu mechanizmów osłabiano skuteczność ich działania.

\section{Oparcie legitymizacji na podziałach dychotomicznych}

Wyraziste roszczenia legitymizacyjne mogą wzmacniać wspólną tożsamość elity, która z kolei wpływa na zaangażowanie oraz spójność organizacyjną. Oparcie legitymizacji na podziałach dychotomicznych (np. my-oni), odgrywa też dużą rolę w mobilizowaniu społeczeństwa (Grauvogel, Von Soest, 2014, s. 637-638). W Kazachstanie reprezentowano wydarzenia w Kirgistanie wyłącznie w negatywnym świetle. Wydaje się dość oczywiste, że protesty społeczne dotyczące zmian systemowych, czy nawet zmiany władzy, nie byłyby życzliwie przyjętym w Kazachstanie scenariuszem. Stąd w konstruowaniu obrazach rzeczywistości usunięto kluczowy z perspektywy Kirgistanu element - akt sprzeciwu suwerennego ludu. Prezydent Kazachstanu Nursułtan Nazarbajew w swoich wystapieniach unikał korzystania ze słowa „rewolucja” zastępując je zwrotami: wydarzenia, chaos, konflikt, czy kryzys. Nie był to również moment nadziei, a raczej zagrożenia dla bezpieczeństwa międzynarodowego. Taka konstrukcja narracji automatycznie pozwalała Kazachstanowi na zajęcie miejsca regionalnego stabilizatora, który jako przewodniczący OBWE miał działać szybko i skutecznie. Warto zaznaczyć, że za tą narracją kryły się takie działania, jak zamykanie granicy kirgisko-kazachskiej, stosowanie blokady gospodarczej, czy najzwyczajniejsze szykany obywateli Kirgistanu przebywających na terenie Kazachstanu (zob. nр.: Маркова, 2010; Хегай, 2010; Назарбаева, 2006, s. 30-31; Назарбаев, 2010а; Назарбаев, 2010е).

Dominującym wątkiem w narracji N. Nazarbajewa było także przeciwstawienie kazachskiego cudu gospodarczego i prosperity (reprezentowanego jako owoc pracy niezastapionego przywódcy), kirgiskiej klęsce gospodarczej. Uwypuklenie kryterium ekonomicznego pozwalało na pominięcie kryterium politycznego, a co za tym idzie, wymazaniu z obrazów rzeczywistości wątków dotyczących walki o wolność i sprawiedliwość społeczna. Przyczyny kirgiskiego kryzysu miały więc mieć wyłącznie podłoże socjalne. Taka definicja sytuacji miała dowodzić niemożliwości rozwiązania podob- 
nego scenariusza w stosunkowo bogatym Kazachstanie (zob. np. Назарбаев, 2010d; Назарбаев, 2011).

W reprezentacji rewolucji oficjalny dyskurs Kazachstanu pomijał milczeniem również kwestię obalenia skorumpowanych rządów. Spychając na drugi plan wątek relacji władzy i ludu, główną uwagę skoncentrowano na konflikcie etnicznym z 2010 r. W ten sposób, krwawe konflikty etniczne stały się nie efektem ubocznym walki o zachowanie status quo, lecz naturalną konsekwencją każdego aktu sprzeciwu wobec władzy. Powyższa reprezentacja kirgiskich wydarzeń, w praktyce umożliwiała delegalizację działań opozycyjnych w Kazachstanie, a co za tym idzie, wzmocnienie tożsamości kazachskiego nacjonalizmu, pozycji kazachskiej elity rządzącej oraz samego prezydenta N. Nazarbajewa. Pozwalała także na taką interpretację, w której odejście prezydenta i zmiana panującej sytuacji mogło doprowadzić kraj nie tylko do problemów gospodarczych, ale i podobnego do Kirgistanu konfliktu etnicznego (zob. np. Назарбаев, 2010b; Назарбаев, 2010c; Назарбаев призвал, 2010; Канафина, Маркова, 2010).

\section{Ksztaltowanie percepcji legitymizacji}

Roszczenia legitymizacyjne, niezależnie od tego, czy odwołujące się do pochodzenia reżimu, cech rządzących, efektywności, czy procedur, bądź kombinacji wszystkich tych elementów, wpływają na percepcję legitymizacji, a tym samym podnoszą szansę akceptacji reżimu. W odróżnieniu od kirgiskiej elity artykułującej swoje roszczenia do władzy przy pomocy populistycznego dyskursu demokratycznego, w Kazachstanie percepcja społeczeństwa i władzy konstruowana była na zasadzie relacji hierarchicznych. Rozwój ekonomiczny kraju, dobrobyt obywateli, przyciagnięcie inwestycji zagranicznych, czy reforma państwowej administracji były centralnymi punktami kolejnych dokumentów, tzw. planów strategicznego rozwoju (np. „Kazachstan-2030”, „Kazachstan-2050”) uroczyście ogłaszanych w trakcie dorocznych posłań do narodu przez prezydenta kraju. Jak zauważa Diana T. Kudaibergenova celem tego typu dokumentów, których wiele formułowano również na szczeblu regionalnym było: 1) zastąpienie starej, radzieckiej „sztywnej ideologii” elastycznymi celami ekonomicznymi, których zakres realizacji mógł zawsze podlegać dodatkowemu uzasadnianiu; 2) równoczesne legitymizowanie reżimu w oczach dwóch odrębnych grup językowych i etnicznych (kazachskich etnonacjonalistów i ludności rosyjskojęzycznej); 3) sprawowanie kontroli nad lokalnymi elitami ekonomicznymi i politycznymi poprzez stworzenie swoistego wzoru dla zachowań oraz tożsamości politycznych. Charakterystyczne, że strategia rozwoju rzadko posługiwała się kategorią narodu, skupiając się na wymiarze państwa, zdolnego osiągnąc sukces gospodarczy i wejść na ścieżkę rozwoju ekonomicznego. Jak podkreślano, sukces strategii „Kazachstan-2030” zależał od „wsparcia obywateli Kazachstanu”, a jednym z jego punktów była ,wewnętrzna stabilność polityczna oraz konsolidacja społeczeństwa”. Dokument wzywał do zjednoczenia, społecznego poparcia i konstruował zbiorowe aspiracje obywateli, a pomysłodawcą i ostatecznym gwarantem jego realizacji był prezydent Nursułtan Nazarbajew (Kudaibergenova, 2015, s. 440 i 444). W ten sposób poza ramami agendy pozostawały kontrowersyjne kwestie: podziały społeczne oraz problem demokratyzacji, czy choćby pluralizacji systemu politycznego. 


\section{Autorytarne ustanawianie i ograniczanie agendy}

Wysiłki legitymizacyjne elit wpływają na kształt dyskursu publicznego ustanawiając granice i układy odniesienia, w ramach których opozycja może artykułować swój głos. Autorytarne ustanawianie i ograniczanie agendy może osłabiać opozycyjne głosy, a także zmusza krytyków reżimu do poruszania się w ramach wyznaczonych przez władzę W budowaniu wodzowskiego charakteru władzy w państwach Azji Centralnej było zaangażowane wiele środków. W ślad za Turkmenistanem, gdzie, za nadzwyczajne zasługi przed państwem i narodem, prezydent Saparmurat Nijazow ogłoszony został Wielkim Turkmenbaszą (Türkmenbaşy), podążał również Kazachstan, nadając N. Nazarbajewowi nowy prezydencki status - Lidera Nacji (Elbasy). Wedle ustawy konstytucyjnej z dnia 14 czerwca 2010 r. miał on stać u genezy kazachskiej państwowości oraz przyczynić się wybitnie do rozwoju suwerennego Kazachstanu jako państwa prawa, demokratycznego, świeckiego, socjalnego. Ustawa usuwała ograniczenia dotyczące prawa do bycia wybranym na stanowisko prezydenta Kazachstanu. Dodatkowo, N. Nazarbajew otrzymał dożywotni immunitet, czyli nie można było pociagnąć go do odpowiedzialności nie tylko za czyny popełnione w trakcie sprawowania funkcji prezydenta, ale także po przejściu na emeryturę. Prezydent, któremu za życia poświęcone były muzea, filmy, spektakle teatralne, wiersze, a jego popiersia zaludniały wiele miejsc publicznych, był również chroniony od wszelkiego rodzaju krytyki. Ustawa stanowiła, że obraza publiczna lub inny zamach na cześć i godność, jak również profanacja wizerunku Lidera Narodu nie są dozwolone i będą karane. Za publicznie obrażanie, na przykład domalowanie wąsa na jego wizerunku, groziła grzywna w wysokości 5,5 tysięcy euro, lub kara pozbawienia wolności na okres jednego roku. Kara była o wiele surowsza w sytuacji gdy obraza nastapiła na łamach środków masowej informacji. Wówczas przewidywana była grzywna w zakresie prawie 8 tys. euro, lub kara pozbawienia wolności do 3 lat (Конституционный, 2010; Вайскопф, 2010).

Krytyczne wobec reżimu głosy, były nie tylko zmuszone do poruszania się w ramach wyznaczonych przez władzę, ale także miały trudność z przebiciem się przez prorządową agendę. Imię prezydenta Kazachstanu Nursułtan było szczególnym instrumentem w działaniach propagandowych. Największa partia „Nur Otan”, czyli Światło Ojczyzny, którego prezesem był sam N. Nazarbajew, w swojej nazwie odnosiła się do pierwszej sylaby imienia prezydenta „Nur”. W 2014 r. w Astanie powstał „Klub Nursułtanów”, gromadzący imienników prezydenta. Finansowane przez Kongres Stanów Zjednoczo-

${ }^{6} \mathrm{Na}$ zjawisko to w odniesieniu do Syrii za rządów Hafiza Al-Asada zwraca uwagę Lisa Wedeen. Jak pisze, kult jednostki oraz spektakle i rytuały polityczne z nim związane zakorzeniają myślenie polityczne obywateli w ob-razach i symbolach oraz wpływają na to, jak ludzie postrzegają siebie jako obywateli. Autorka zwraca również uwagę na to, w jak wielkim stopniu opozycyjne dyskursy poruszały się w ramach wyznaczonych przez hegemo-niczną ideologię reżimu. Nawet żarty polityczne korzystały z wątków pojawiających się w oficjalnej propagan-dzie (zob. Wedeen, 1999, s. 19). Podobne mechanizmy dostrzega David Lewis na przykładzie Kazachstanu. Autor analizuje reakcję opozycyjnych wobec władzy bloggerów na wydarzenia protestacyjne w Żana-Ozen, wskazując, że wiele aspektów ich dyskursu reprodukowało elementy formuły legitymizacyjnej władzy. Na przy-kład, blogerzy w swoich wypowiedziach posługiwali się dyskursem technokratyczno-menedżerskim, który de-polityzował protesty, pozbawiał protestujących podmiotowości oraz pozycjonował władze lokalne w pozycji efektywnych i kompetentnych podmiotów (Lewis, 2016, s. 432). 
nych Radio Azattyq ${ }^{7}$ w lipcu 2015 r. przeprowadziło wywiady z imiennikami prezydenta. W audycji dzielili się oni swoimi marzeniami, osiagnięciami i rozczarowaniami. Materiał ukazywał również problemy współczesnego Kazachstanu oraz trudności życia swoich bohaterów, np. historię chłopca Nursułtan Żajdaruly mieszkającego wraz z rodzicami w dwupokojowej wiejskiej chatce, bez kanalizacji, wody, czy gazociagu. Bohater wywiadu, tak jak wielu jego rówieśników, codziennie uczęszcza do szkoły piechotą ok. 3 km (Лаханулы, 2015; Меделбек, 2015).

Powyższy przekaz przygotowany przez dziennikarzy Radio Azattyq mocno kontrastował z rządowym wizerunkiem bogatego, świetnie prosperującego Kazachstanu. Na reakcję władzy nie trzeba było długo czekać. W 2015 r., na Dzień Pierwszego Prezydenta Respubliki Kazachstan, święto państwowe od 2012 r., zorganizowano konkurs „Nazywam się Nursułtan” (w oryg. - Менің атым Нұрсұлтан). Uczestniczyły w nim osoby o imieniu Nursułtan w wieku od pięciu do trzydziestu lat. Idea szeroko omawianego $\mathrm{w}$ mediach konkursu polegała na napisaniu niewielkiej pracy opowiadającej o własnych doświadczeniach życiowych imienników prezydenta. Odgórnie ordynowany konkurs miał stać się okazją do wygłoszenia oddolnych peanów na cześć prezydenta, które osłabiłyby siłę alternatywnych głosów. W ten sposób konkursy, święta, rozwiązania prawne oraz rozmaite inne działania władzy zakorzeniały w myśleniu politycznym obywateli kult jednostki. Dominacja w przestrzeni symbolicznej wpływać miała na to, jak mieszkańcy Kazachstanu postrzegali siebie jako obywateli. Warto wspomnieć, że w Kazachstanie w 2015 r. żyło ponad 38 tys. imienników prezydenta, z czego ponad 23 tys. chłopców nazwano Nursułtanem ku czci prezydenta N. Nazarbajewa (Беляков, Энгельгардт, 2015; Бекбасова, 2014).

\section{Interakcyjny charakter legitymizacji}

Interakcyjny charakter legitymizacji oznacza, że reżimy nieustannie testują swoje formuły legitymizacyjne i monitorują opinię publiczną, reagując na postrzegane deficyty poprzez formułowanie nowych idei i reguł uzasadniających władzę. Ponadto, zmiany formuł legitymizacyjnych na poziomie elit mogą być ważnym, pośrednim wskaźnikiem przesunięć poparcia społecznego i zmian świadomości społecznej. Testem gotowości kazachskiego społeczeństwa do uznania prezydenta N. Nazarbajewa za chana i wprowadzenia monarchii był artykuł zięcia prezydenta Rachata Alijewa (ówczesnego zastępcy ministra Spraw Zagranicznych) pod tytułem Republikostan badź Kazachski Sultanat. Jakiego wyboru dokonamy? opublikowany w dniu 1 września 2006 r. w prorządowej gazecie „Karawan”. Wedle autora monarchia, w odróżnieniu od ustroju republikańskiego, miała współgrać nie tylko z kazachską tradycją rodową, ale i z doświadczeniem światowym, zwłaszcza brytyjskim. Monarchia miała być również gwarantem bezpieczeństwa, wygody i demokracji, podczas gdy republika stwarza warunki dla szerzenia korupcji i powstaniu dyktatorów. Otóż właśnie monarcha, a nie prezydent, mógłby zapewnić społeczeństwu stabilność na przestrzeni długiego okresu historycznego (Алиев, 2006).

\footnotetext{
${ }^{7}$ Kazachska sekcja rozgłośni Radio Wolna Europa/Radio Swoboda.
} 
Publikacja powyższej, dość kontrowersyjnej propozycji wywołała wśród elity politycznej szok i niepewność, co do właściwego sposobu reakcji. Niejasne było, czy jest to rodzaj balona próbnego, który z jednej strony ma ujawnić gotowość do krytyki pomysłów płynących z kręgu władzy, z drugiej, wyprodukować serwilizm aparatu. Jeśli miałyby być to poważne zamiary samego N. Nazarbajewa, które niedługo i tak wejdą w życie, to szybkość poparcia oznaczała dla poszczególnych członków elity władzy wzmocnienie własnej pozycji względem lidera. Jednak w tym przypadku idee nie trafiły na podatny grunt. Analiza zawartości materiałów kazachskich agencji prasowych i serwisów internetowych omawiających kwestie rozwoju sytuacji społeczno-politycznej w Kazachstanie we wrześniu 2006 r. wykazała, że temat ten, ze względu na stopień zainteresowania i cytowalność, zajął zaledwie trzecie i czwarte miejsce, interesując media w takim samym stopniu, co wypadek z obwodu Karaganda, gdzie wskutek wybuchu metanu w kopalni im. Lenina doszło do śmierci 41 górników. Debata ustrojowa wyprzedzona została przez kwestie zmian kadrowych oraz problem rosnącej liczby dzieci zakażonych HIV w Południowym Kazachstanie. Kwestia wprowadzenia monarchii i ustanowienia oficjalnego tytułu chana nie została nawet podchwycona przez prorządowe media. Większe zainteresowanie tematem wykazały opozycyjne strony internetowe (np. w ciagu jednego miesiąca kub.kz opublikował 10 artykułów, zonakz.net natomiast 12 artykułów) (Контент-анализ, 2006). Próby kontynuacji tematu przez „Karawan” nie uruchomiły debaty. Brakowało reakcji elit, nie wypowiadał się również sam N. Nazarbajew. Po kilku miesiącach milczenia z obu stron, N. Nazarbajew w trakcie swej wizyty w Hiszpanii ogłosił, że monarchia jako forma rządów nie pasuje do demokratycznego Kazachstanu (Алиев, 2009, s. 351-356) ${ }^{8}$.

\section{Dostarczanie obywatelom szerszego obrazu nadającego znaczenia rzeczywistości}

Oficjalne ramy legitymizacyjne we wszystkich systemach, pełnią funkcję epistemiczną wpływając na sposób interpretacji konkretnych polityk, czy wydarzeń, poprzez dostarczanie obywatelom szerszego obrazu nadającego znaczenia rzeczywistości. W przypadku gwałtownych zmian, problemów ekonomicznych, czy innych trudności reżimu, ramy te pozwalają na wyjaśnianie i osłabianie ewentualnych zaburzeń w społecznej percepcji reżimu (Bondes, Heep, 2013, s. 320). W Uzbekistanie wysoki poziom represyjności systemu, wyrażający się m.in. więzieniem obywateli bez procesu sądowego, porwaniami organizowanymi przez funkcjonariuszy służby bezpieczeństwa, zabójstwami, powszechnością tortur, przymusowym leczeniem psychiatrycznym przeciwników politycznych w szpitalach-więzieniach, restrykcyjnymi wymogami otrzymania zezwolenia na wyjazd z kraju, czy radykalnym thumieniem wszelkich przejawów religijności islamskiej wymagały systemowych uzasadnień (Human Rights Watch, 2007). Systematyczne odwołania do dyskursu stabilności i bezpieczeństwa stało się ważnym instrumentem uzasadniania państwowego terroru. Wedle oficjalnej ramy legitymizacyjnej źródłem permanentnego zagrożenia był radykalizm, fundamentalizm $\mathrm{i}$ terroryzm islamski. Mariya Y. Omelicheva w oparciu o ana-

${ }^{8}$ O mechanizmach interakcyjnego charakteru legitymizacji w Kazachstanie zob. szerzej O. Kazancewa i K. Toguzbajew (Казанцева, 2011; Тогузбаев, 2011). 
lizę m.in. dorocznych przemówień N. Nazarbajewa i I. Karimowa wygłoszonych w latach 1997-2015 ustaliła, że odniesienia do Islamu pojawiały się najczęściej w kontekście aktów terrorystycznych, zagrożenia religijnym ekstremizmem oraz uczestnictwem Kazachstanu i Uzbekistanu w narodowych, regionalnych i międzynarodowych inicjatywach związanych ze zwalczaniem terroryzmu (Omelicheva, 2016, s. 154). Instrumentalne wykorzystywanie zagrożenia pozwalało wzmacniać władzę poprzez mniej lub bardziej subtelne formy ustanawiania ekwiwalencji pomiędzy opozycją polityczną a religijnym ekstremizmem. Wykorzystywanie ramy „wojny z terroryzmem” wywodzącej się z amerykańskiego dyskursu publicznego normalizowało różnego rodzaju działania polityczne poprzez wpisywanie ich w kontekst międzynarodowej reakcji na zagrożenie terrorystyczne.

Dowodem członkostwa w zakazanych organizacjach religijnych oraz pretekstem do kontrolowania wybranych obywateli przez przedstawicieli MSW Uzbekistanu był wygląd (długi zarost, ubiór) czy religijność (np. częstotliwość wizyt w meczecie) ${ }^{9}$. Oznaczało to, że potencjalnej kontroli podlegała praktycznie cała populacja kraju, którego ponad $90 \%$ mieszkańców to muzułmanie. O sile oficjalnej definicji rzeczywistości, kategoryzującej wrogów według bieżącego interesu władzy świadczy choćby przykład aresztowania Aramaisa Awakiana. Został on oskarżony na podstawie pięciu artykułów kodeksu karnego, takich jak: zamach na porządek konstytucyjny (art. 159), dywersja (art. 161), produkcja i rozpowszechnienie materiałów stanowiących zagrożenie dla bezpieczeństwa i porządku publicznego (art. 244-1), tworzenie, kierownictwo, uczestnictwo w religijnych ekstremistycznych, separatystycznych, fundamentalistycznych lub innych zakazanych organizacjach (art. 244-2) oraz kradzież (art. 169). Aparatu represji nie ograniczał fakt, że A. Awakian, nie mógł być islamskim ekstremistą, gdyż jest chrześcijaninem. Dowodem jego domniemanej antyrządowej działalności miała być broda kojarzona w rządowej propagandzie z islamskim terroryzmem. Nie pomogły wyjaśnienia, że jako Ormianin po śmierci kuzyna odbywał żałobę i nie golił brody od 40 dni (Узбекистан, 2016).

\section{Stabilne poparcie stosunkowo wąskiego kręgu zwolenników}

Adresatem roszczeń legitymizacyjnych niekoniecznie musi być cała populacja, dla skuteczności zabiegów uprawomocniających wystarczy stabilne poparcie stosunkowo wąskiego kręgu zwolenników. Ważne, by byli oni uplasowani w tych miejscach hierarchii politycznej i zawodowej, która pozwalałaby na redystrybucję potencjalnych zachęt materialnych (np. gotówki, możliwości awansu, dostępu do społecznie cenionych dóbr ale też szantażu) oraz pozycjonowałyby ich jako liderów opinii. Natomiast w odniesieniu do szerszych kręgów społecznych strategie legitymizacji uzupełniane są o szantaż, czy też materialne korzyści, a także represje w przypadku skonsolidowanych autorytaryzmów (Schatz, 2009, s. 206).

Dobrym przykładem jest ewolucja statusu prawnego rządzącego już od 1990 r. prezydenta N. Nazarbajewa. O ile na początku otrzymania niepodległości w Kazachstanie prezydent miał ograniczone względem parlamentu prerogatywy, to po upływie 25 lat, stał

${ }_{9}$ Opinia przedstawiciela Działu do spraw walki z terroryzmem MSW Uzbekistanu (рatrz: Одил, 2002). 
się on w państwie postacią kluczową. Procesom osłabiania i podporządkowania innych ośrodków władzy, eliminacji opozycji oraz budowaniu kultu jednostki towarzyszyło zawsze wsparcie stosunkowo wąskiego kręgu zwolenników. Jednym z takich ośrodków, zapewniających instytucjonalizowane wsparcie było Zgromadzenie Narodu (w oryg. - Қазақстан халқы ассамблеясы). Ich przedstawiciele zasiadali w ważnych gremiach, takich jak parlament oraz w rozmaitych radach państwowego znaczenia.

Instytucja ta oficjalnie miała katalizować uczestnictwo różnych wspólnot etnicznych w politycznym i kulturowym rozwoju kraju, jednak wedle Rachata Alijewa, byłego zięcia prezydenta, pełniła ona również rolę „,koguta-prowokatora”, który jako pierwszy miał ogłaszać kolejne pomysły N. Nazarbajewa w celu testowania reakcji otoczenia, ale także produkowania populistycznego typu mobilizacji (Jansen, 2011, s. 76). Gdy prezydent mimo zakończenia kadencji, wbrew zasadom konstytucyjnym, pragnął uczestniczyć w kolejnych wyborach, to za każdym razem, Zgromadzenie Narodu nie tylko wyrażało ten pomysł we własnym imieniu, ale i namawiało go do uczestnictwa w wyborach w imieniu i na rozkaz całego narodu wieloetnicznego Kazachstanu (Алиев, 2009, s. 308).

W lutym 2015 r. uczestnicy Forum narodu Kazachstanu „Mój Kazachstan” („Менің Қазақстаным") poświęconego 20-leciu Zgromadzenia Narodu skierowali apel do prezydenta i narodu Kazachstanu: „Świadomi swojej odpowiedzialności za przyszłość, w oparciu o najwyższe interesy narodu i kraju, realizując swój obywatelski i patriotyczny obowiązek, prosimy o wysunięcie kandydatury Lidera Nacji, pierwszego prezydenta Kazachstanu N. Nazarbajewa do uczestnictwa w nadzwyczajnych wyborach prezydenckich. 20 lat temu z inicjatywy Zgromadzenia Narodu Kazachstanu zostały podjęte właściwe kroki, które zadecydowały o sukcesie niepodległego Kazachstanu. Również dziś wzywamy wszystkich obywateli naszego kraju, aby dla dobra przyszłych pokoleń poparli nasz apel jako jedyny właściwy wybór na rzecz dobrobytu i pomyślności narodu Kazachstanu! (Байманов, 2015)". W dniu 26 kwietnia 2015 r. odbyły się przedterminowe wybory prezydenta Kazachstanu, w których N. Nazarbajew otrzymał 97,75\% głosów, przy frekwencji $95,22 \%$ uprawnionych do głosowania. Rozpoczął on tym samym swoją piątą kadencję rządów. Podobne do funkcjonującego w Kazachstanie Zgromadzenia Narodu, instytucjonalizowane poparcie stosunkowo wąskiego kręgu zwolenników było wykorzystywane również w innych państwach Azji Centralnej. W Turkmenistanie był to funkcjonujący obok parlamentu Medżlis, równoległy organ przedstawicielski - Chalk Maslachaty, czyli Rada Ludowa. Instytucja ta oficjalnie gromadząca liderów opinii oraz najbardziej szanowanych przedstawicieli ludu jeszcze w grudniu 1999 r. ogłosiła S. Nijazowa dożywotnim prezydentem (International Crisis Group, 2003, 2004).

\section{Podsumowanie}

Utrzymywanie stabilności reżimów niedemokratycznych wymaga rekombinacji różnego rodzaju działań i mechanizmów, spośród których kluczową rolę odgrywają legitymizacja, kooptacja i represja. Jak świadczą przytoczone w artykule przykłady, represji i legitymizacji nie da się od siebie zupełnie oddzielić, jedna stanowić może i często stanowi warunek drugiej. $Z$ jednej strony już sama groźba użycia represji jest skutecznym 
mechanizmem uciszania potencjalnych przeciwników zdolnych do wysunięcia roszczeń kontrlegitymizacyjnych, a aparat represji, czy podporządkowane władzy media wpływać mogą na to, co pojawi się na agendzie politycznej.

Z drugiej, akty represyjne same są obiektem legitymizacji, wtórnie wzmacniając pozycję sprawujących władzę. Legitymizacja nie jest ponadto mechanizmem odgórnym, który opiera się na centralnie transmitowanym do społeczeństwa przekazie. Jest raczej skomplikowaną, opartą na aktywności wielu aktorów siecią komunikacji, która uwzględnia reakcje społeczne na budzące potencjalne protesty decyzje władzy.

Po trzecie, legitymizacja niekoniecznie adresowana być musi do całej populacji. Zróżnicowana redystrybucja władzy, bogactwa, prestiżu, czy kapitału społecznego powoduje, że wystarczy pozyskanie prawomocności w oczach wybranych jednostek, czy grup podatnych na system nagród, czy kar w przypadku bardziej represyjnych reżimów.

\section{Bibliografia}

Amnesty International (1997), Death Sentences and Executions in 1996, 24.03.1997, AI Index: ACT 51/01/97.

Anceschi L. (2015), The End of the Nazarbayev's Dream, „Open Democracy” 16.11.2015, https://www. opendemocracy.net/luca-anceschi/end-of-nazarbayev-dream, 3.05.2016.

Bondes M., Heep S. (2013), Conceptualizing the Relationship Between Persuasion and Legitimacy: Official Framing in the Case of the Chinese Communist Party, „Journal of Chinese Political Science", t. 18, nr 4.

Brancati D. (2014), Democratic Authoritarianism: Origins and Effects, „Annual Review of Political Science", t. 17.

Diamond L. J. (2002), Thinking About Hybrid Regimes, ,Journal of Democracy”, t. 13, nr 2.

Finkel E., Brudny Y. M. (2012), No more colour! Authoritarian regimes and colour revolutions in Eurasia, „Democratization”, t. 19, nr 1.

Freedman E. (2009), When a Democratic Revolution Isn't Democratic or Revolutionary. Press Restraints and Press Freedoms After Kyrgyzstan's Tulip Revolution, „Journalism”, t. 10, nr 6.

Freedom House (2002-2012), Worst of the Worst: The World's Most Repressive Societies.

Gerschewski J. (2013), The Three Pillars of Stability: Legitimation, Repression, and Co-optation in Autocratic Regimes, „Democratization”, t. 20, nr 1.

Grauvogel J., Von Soest Ch. (2014), Claims to legitimacy count: Why sanctions fail to instigate democratisation in authoritarian regimes, "European Journal of Political Research", t. 53, nr 4.

Halonen A., Frazier K. (2010), W cieniu świętej księgi, Wołowiec.

Human Rights Watch (2007), Uzbekistan. Nowhere to Turn. Torture and Ill-treatment in Uzbekistan, New York, vol. 19, no. 6(D).

Huntington S. P. (1995), Trzecia fala demokratyzacji, Warszawa.

International Crisis Group (2003), Cracks in the Marble: Turkmenistan's Failing Dictatorship, „Asia Report" 17.01.2003, nr 44, Osh/Brussels.

International Crisis Group (2004), Repression and Regression in Turkmenistan: A New International Strategy, „Asia Report” 4.11.2004, nr 85, Osh/Brussels.

Jansen R. S. (2011), Populist Mobilization: A New Theoretical Approach to Populism, "Sociological Theory", t. 29, nr 2.

Kudaibergenova D. T. (2015), The Ideology of Development and Legitimation: Beyond 'Kazakhstan 2030', „Central Asian Survey”, t. 34, nr 4. 
Lewis D. (2016), Blogging Zhanaozen: hegemonic discourse and authoritarian resilience in Kazakhstan, "Central Asian Survey", t. 35, nr 3.

Levitsky S., Way L. A. (2010), Competitive Authoritarianism. Hybrid Regimes After the Cold War, Cambridge.

Magaloni B. (2006), Voting for Autocracy. Hegemonic Party Survival and its Demise in Mexico, Cambridge.

Morse Y. L. (2012), The Era of Electoral Authoritarianism, „World Politics”, t. 64, nr 1.

Omelicheva M. Y. (2016), Islam and Power Legitimation: Instrumentalisation of Religion in Central Asian States, "Contemporary Politics", t. 22, nr 2.

Polese A., Ó Beacháin D. (2011), The Color Revolution Virus and Authoritarian Antidotes. Political Protest and Regime Counterattacks in Post-Communist Spaces, „Demokratizatsiya”, t. 19, nr 2.

Richter A. (2008), Post-Soviet Perspective on Censorship and Freedom of The Media: An Overview, „International Communication Gazette”, t. 70, $\mathrm{nr} 5$.

Sandby-Thomas P. (2011), Legitimating the Chinese Communist Party since Tiananmen. A critical Analysis of the Stability Discourse, Routledge.

Schatz E. (2009), The Soft Authoritarian Tool Kit: Agenda-Setting Power in Kazakhstan and Kyrgyzstan, "Comparative Politics", t. 41, nr 2.

Schedler A. (2006), The Logic of Electoral Authoritarianism, w: Electoral Authoritarianism: The Dynamics of Unfree Competition, red. A. Schedler, Boulder.

Schlumberger O. (2010), Opening Old Bottles in Search of New Wine: On Nondemocratic Legitimacy in the Middle East, "Middle East Critique", t. 19, nr 3.

Shukuralieva N., Sobczak W. (2014), Kara śmierci w państwach Azji Centralnej, „Państwo i Prawo”, Komitet Nauk Prawnych Polskiej Akademii Nauk, nr 9.

The World's Most Repressive Societies (2002-2012), Washington-New York.

Weber M. (2002), Gospodarka i społeczeństwo. Zarys socjologii rozumiejacej, Warszawa.

Wedeen L. (1999), Ambiguities of Domination. Politics, Rhetoric and Symbols in Contemporary Syria, Chicago-London.

Алиев Р. (2006), Республикостан или Казахский Султанат. Какой выбор мы сделаем?, Республиканская газета „Караван” 1.09.2006.

Алиев Р. (2009), Крестный тесть. Документальная повесть, Берлин.

Байманов Д. (2015), АНК просит Нурсултана Назарбаева принять участие во внеочередных президентских выборах, http://www.inform.kz/rus/article/2750975, 28.02.2015.

Бекбасова А. (2014), Клуб Нурсултанов создали в Астане, http://ratel.kz/raw/klub_nursultanov_ sozdali_v_astane/, 18.11.2014.

Беляков Д., Энгельгардт П. (20015), Казахстан выбирает лучшего Нурсултана, „Настоящее время. Казахстан” 13.11.2015.

В Кыргызстане за 9 месяцев 2011 года прошло 1013 митингов и акций протеста (2011), АКИpress, 3.10.2011.

Вайскопф А. (2010), ,Елбасы” Назарбаев, http://dw.com/p/NrYG, 15.06.

Казанцева О. (2011), Закон принят. Слово за Президентом, http://www.kazpravda.kz/c/1295059991, 15.01.2011.

Канафина Ж., Маркова Н. (2010), Ош бросает в дрожь, Республиканская газета „Караван” 18.06.2010, nr 25.

Конституционный Закон Республики Казахстан от 14 июня 2010 г. № 289-IV ЗРК О внесении изменений и дополнений в некоторые конституционные законы Республики Казахстан по вопросам совершенствования законодательства в сфере обеспечения деятельности Первого Президента Республики Казахстан - Лидера Нации, „Казахстанская правда” 15.06.2010. 
Контент-анализ материалов казахстанских информационных агентств и интернет-сайтов по вопросам развития социально-политической обстановки в Казахстане за сентябрь 2006 г. По материалам, предоставленным ТОО „Центр социальных технологий”. Информационноаналитический Центр по изучению общественно-политических процессов на постсоветском пространстве, Алматы 2.11.2006.

Лаханулы Н. (2015), Школьник Нурсултан, http://rus.azattyq.org/a/kazakhstan_nursultan_school_ boy/27107382.html, 6.07.2015.

Мамедова С. (2007), Срок как казнь, „Оазис” nr 6 (50), 03.2007.

Маркова Н. (2010), Бишкек в огне, Республиканская газета „Караван” 9.04.2010, nr 15.

Меделбек Р. (2015), Магистрант Нурсултан, http://rus.azattyq.org/a/kazakhstan_nursultan_ magistrant_rus/27108738.html, 6.07.2015.

Назарбаев Н. А. (2010а), Выступление на ІХ Евразийском медиа-форуме, Алматы, 27.04.2010.

Назарбаев Н. А. (2010b), Интервью информационному агентству „Интерфакс”, „Российской газете”, и телеканалу „Вести”, 21.07.2010.

Назарбаев Н. А. (2010c), Выступление на XVI сессии Ассамблеи народа Казахстана, Астана, 20.10.2010.

Назарбаев Н. А. (2010d), Выступление на торжественном собрании, посвященном Дню Независимости Республики Казахстан, Астана, Тәуелсіздік сарайы, 15.12.2010.

Назарбаев Н. Ә. (2010е), ЕҚЫҰ Саммитін биылвы жылдың 1-2 желтоқссаны күндері Астанада өткізу туралы шешімнің қ̧абылдануына байланысты мәлімдемесі, 5.08.2010.

Назарбаев Н. Ә. (2011), Қазақ̧стан Республикасы Президенті қ̧ызметіне кірісуі салтанатында сөйлеген сөзі, Астана, Тәуелсіздік сарайы, 8.04.2011.

Назарбаев призвал казахстанщев укреплять единство в стране и не повторять ошибок Кыргызстана (2010), http://ca-news.org/news/552661, 7.12.2010.

Назарбаева Д. (2006), Дорожная карта преобразований Казахстана, в: Динамика политических прочессов в Централной Азии, ред. Райнхард Крумм, «Искандер», FES, Алматы.

Одил У. (2002), Борода в Узбекистане - важная улика, http://www.fergananews.com/articles/705, 8.08.2002.

Правозащитный центр “Мемориал” (1999), Права человека в Туркменистане (обзор событий за январь-апрель 1999 г.), Информационный центр по правам человека в Центральной Азии, Москва.

Тогузбаев К. (2011), ДУМК осуществил разъяснение о референдуме вне своего годового плана, http://rus.azattyq.org/content/dumk_ongar_khadzhy_kazakhstan_mechet_ referendum/2283603.html, 21.01.2011.

Узбекистан: В Джизаке судят фермера-армянина, обвиняемого в исламском экстремизме, http:// www.fergananews.com/articles/8848, 29.01.2016.

УК Туркменистана от 1.01.1998.

Хегай М. (2010), “Mbl - диктаторы, но это временно...”, Республиканская газета „Караван” 23.04.2010, $\mathrm{nr} 17$.

\section{Conditions of Legitimacy in Authoritarian Systems. The Case of Central Asian States}

\section{Summary}

Legitimacy along with co-optation and repression are the three main pillars of the stability of autocratic regimes. Explanation of their relative stability should take into account the complex relationships between these variables. The elites of authoritarian regimes systematically formulate legitimacy claims 
in order to justify their power, and the processes of institutionalization and effective distribution of these claims depends on a number of factors and mechanisms. The purpose of this paper is to analyze these factors and mechanisms of legitimacy contributing to the stability of authoritarian states by drawing on the example of Central Asian republics.

Key words: legitimacy, repression, co-optation, Central Asia, authoritarianism 